University of Nebraska - Lincoln

DigitalCommons@University of Nebraska - Lincoln

8-1999

\title{
An Investigation into the Possibility of Transmission of Tick-Borne Pathogens Via Blood Transfusion
}

\author{
P. M. Arguin
}

J. Singleton

L. D. Rotz

E. Marston

T. A. Treadwell

See next page for additional authors

Follow this and additional works at: https://digitalcommons.unl.edu/publichealthresources

Part of the Public Health Commons

Arguin, P. M.; Singleton, J.; Rotz, L. D.; Marston, E.; Treadwell, T. A.; Slater, K.; Chamberland, M.; Schwartz, A.; Tengelsen, L.; Olson, J. G.; Childs, J. E.; and Task Force, Transfusion-Associated Tick-Borne Illness, "An Investigation into the Possibility of Transmission of Tick-Borne Pathogens Via Blood Transfusion" (1999). Public Health Resources. 1.

https://digitalcommons.unl.edu/publichealthresources/1

This Article is brought to you for free and open access by the Public Health Resources at DigitalCommons@University of Nebraska - Lincoln. It has been accepted for inclusion in Public Health Resources by an authorized administrator of DigitalCommons@University of Nebraska - Lincoln. 


\section{Authors}

P. M. Arguin, J. Singleton, L. D. Rotz, E. Marston, T. A. Treadwell, K. Slater, M. Chamberland, A. Schwartz, L. Tengelsen, J. G. Olson, J. E. Childs, and Transfusion-Associated Tick-Borne Illness Task Force 


\title{
An investigation into the possibility of transmission of tick-borne pathogens via blood transfusion
}

\author{
P.M. Arguin, J. Singleton, L.D. Rotz, E. Marston, T.A. Treadwell, K. Slater, \\ M. Chamberland, A. Schwartz, L. Tengelsen, J.G. Olson, J.E. Childs, \\ and theTransfusion-Associated Tick-Bornelllness Task Force
}

BACKGROUND: Tick-borne illnesses were diagnosed in a group of National Guard members, including some who had donated blood a few days before the onset of symptoms. A voluntary recall of those blood components was issued and a multistate investigation was conducted to determine if transfusion-transmitted illness had occurred.

STUDY DESIGN AND METHODS: Donors and recipients were asked to complete questionnaires regarding symptoms and risk factors for infection and to provide blood samples for laboratory analysis.

RESULTS: Among National Guard personnel who donated blood, 12 individuals were found to have a confirmed or probable case of Rocky Mountain spotted fever or ehrlichiosis. A total of 320 units (platelets or packed red cells) from 377 donors were transfused into 129 recipients. Although 10 recipients received units from National Guard personnel with confirmed or probable infection, none became ill.

CONCLUSION: Transfusion-transmitted illness did not occur. Despite the awareness of the risk for tick-borne diseases and the use of tick-preventive measures, many National Guard personnel reported exposure to ticks. In addition to augmenting current tick-preventive measures, scheduling blood drives before rather than after field exercises could further reduce the potential for transmission of tick-borne pathogens. atrogenic transmission of tick-borne pathogens by blood transfusion has been well documented for Babesia species. ${ }^{1-5}$ There has been one documented case of Rickettsia rickettsii, the causative agent of Rocky Mountain spotted fever (RMSF), being transmitted by blood transfusion. In that case, the donor developed symptoms 3 days after his donation and subsequently died. After a 6-day incubation period, the recipient also developed symptoms of fever and headache, and his illness was confirmed as RMSF by serologic testing. ${ }^{6}$ Other tick-borne pathogens, including Borrelia and Ehrlichia species, have the same potential, but transmission by transfusion has not yet been documented. ${ }^{2,7-10}$

In the southern United States, the two most serious human diseases resulting from the bite of an infected tick are RMSF and ehrlichiosis. RMSF is an acute febrile illness

ABBREVIATIONS: $\mathrm{CDC}=$ Centers for Disease Control and Pre vention; $\mathrm{DOD}=$ Department of Defense; $\mathrm{EI} A=$ =nzyme immunoassay; FDA =Food and Drug Administration; IFA =immunofluorescent assay; RMSF = Rocky Mountain spotted fever; SFG = spotted fever group.

From the Viral and Rickettsial Zoonoses Branch; the Office of the Director; and Biometrics Activity, Division of Viral and Rickettsial Diseases; and the Division of Vector-Borne Infectious Diseases, National Center for Infectious Diseases, Centers for Disease Control and Prevention, Atlanta, Georgia; the Arkansas Department of Health, Little Rock, Arkansas; the Mississippi State Department of Health, Jackson, Mississippi; the Oklahoma State Department of Health, Oklahoma City, Oklahoma; the Nebraska Health and Human Services System, Lincoln, Nebraska; and the lowa Department of Public Health and Iowa National Guard, Des Moines, lowa.

Address reprint requests to: Paul M. Arguin, MD, Viral and Rickettsial Zoonoses Branch, Centers for Disease Control and Prevention, 1600 Clifton Road, MS G-13, Atlanta, GA 30333; email: pma0@cdc.gov.

Received for publication September 10, 1998; revision received and accepted December 15, 1998.

TRANSFUSION 1999;39:828-833. 
characterized by malaise, myalgia, headache, and, in approximately two-thirds of the cases, a petechial rash on the extremities, including the palms and soles. Untreated, the illness lasts 2-3 weeks with up to 30 percent case fatalities. ${ }^{11,12}$ There are two clinically similar yet distinct forms of human ehrlichiosis: human monocytic ehrlichiosis, caused by $E$. chaffeensis, and human granulocytic ehrlichiosis, caused by a not-yet-named Ehrlichia species closely related to E. equi and E. phagocytophila. Both agents cause an illness similar to RMSF, usually without the characteristic rash, and frequently with the additional laboratory findings of leukopenia, thrombocytopenia, and elevated hepatic aminotransferases. ${ }^{13}$ All three pathogens are transmitted by bites from infected ticks. The antibiotic treatment of choice is doxycycline.

In June 1997, the Iowa State Department of Public Health identified 10 lowa National Guard members with an acuteillness characterized by fever, headache, malaise, and myalgia; six of these individualsalso reported a rash. Guard members became ill shortly after returning from their 2week, annual field training exercises at a military base in Arkansas, during which they experienced extensive tick exposure. In addition, several of the ill guard members reported that they had donated blood 24 to 72 hours before the onset of their symptoms. Preliminary testing of their serum samples by the Centers for Disease Control and Prevention (CDC) and lowa Department of Public Health laboratories detected antibodies reactive with spotted fever group (SFG) rickettsia in four of the ill guard members.

In responseto these reports, a voluntary recall of blood components collected at the base during three previous blood drives between May 17 and June 29 wasissued on July 3. The CDC, in collaboration with the National Guard and state health departments, initiated an investigation to determinethe number of blood donors who developed atickborneillnessand ascertain if recipients of transfused blood components developed a tick-borne illness that could be linked to an infected donor.

\section{MATERIALS AND METHODS}

Theblood collection agency records were reviewed to identify donors who had participated in blood drives held at the military base during May through June, 1997. Additional donors were identified through the National Guard and state health departments whose personnel attempted to contactall guard members who trained at that military base during the training season. Guard members who participated in the blood drives were asked to complete a selfadministered questionnaire that included information about their training experience at the base, illness experienced at, or since returning from, the militarybase, and any associated medical care, prior medical history of tick-borne disease, tick exposure, and tick-bite prevention measures.
Once a list of all the donors was obtained, the number and type of components prepared from each donation, wherethecomponents had been distributed (i.e., consignees), and each component's disposition (e.g., transfused, destroyed) were ascertained. On the basis of the results of the donor's blood tests, physicians of patients who had received potentially infectious, recalled blood components were contacted. These physicians wereadvised of thesigns and symptoms of RMSF and ehrlichiosis and the appropriate treatment if disease were detected in a recipient. If a tick-borne infection was suspected in the recipient, or if a recipient had received components from a donor subsequently shown to have had a confirmed or probable tickborne disease (see below), then theattending physician was requested to submit a serum specimen and complete a questionnaire detailing the recipient's medical history, recent tick exposure, and their medical condition since receiving the recalled blood component.

Laboratory testing for antibodies reactive with ticktransmitted pathogens and DNA from tick-transmitted pathogens was first performed on retention samples availablefrom most (98\%) of the donated units of blood. Because serologic confirmation of a case of tick-borne disease requires paired testing of convalescent- and acute-phase samples, an effort was made to contact all donors through their National Guard units at least 6 weeks after the original donation. This effort was coordinated by state health department and National Guard personnel and relied primarily on collections at regular musters. However, donors not present were repeatedly requested by phoneto provide blood through a local health clinic.

Sera were tested by immunofluorescent assay (IFA) for IgG and IgM antibodies reactive with $\mathrm{R}$. rickettsii, $\mathrm{E}$. chaffeensis, and the human granulocytic ehrlichiosis agent and by an investigational enzyme immunoassay (EIA) for IgG and IgM antibody to SFG rickettsiae. ${ }^{14,15}$ An IFA result was considered positive at a titer of $\geq 64$ and an EIA result at a titer of $\geq 100$ for these agents. Samples from donors reporting an erythema migrans-like rash were also tested by EIA and, when required, by Western immunoblot, for antibodies to Borrelia burgdorferi, the agent of Lyme disease. ${ }^{16}$

Total DNA was extracted from whole blood recovered from the retention samples. Attempts to amplify specific DNA of rickettsial origin by polymerasechain reaction used primers for the citrate synthase gene, RpCS.877p and RpCS. $1258 n,{ }^{17}$ for the detection of R. rickettsii, and primers $\mathrm{HE} 1$ and $\mathrm{HE} 3$, targeting the $16 \mathrm{~S}$ ribosomal RNA gene, ${ }^{18}$ for E. chaffeensis. The detection sensitivity of the R. rickettsi assay, as applied to control samples of spiked whole blood, was between 10 and 100 organisms per $200 \mu \mathrm{L}$ of blood. The detection sensitivity of the $\mathrm{E}$. chaffeensis assay, as applied to control samples of spiked whole blood, was 1000 infected cells per $1 \mathrm{~mL}$ of blood.

Cases of RMSF and ehrlichiosis were classified as confirmed, probable, asymptomatic seroconversion, or past 
infection by using both clinical and laboratory criteria (Table 1). A clinically compatible illness was defined as fever, or rash plusat least oneother symptom (e.g., headache, arthralgia, or malaise).

Data collected from the questionnaires were analyzed with the use of statistical software (SPSS for Windows version 7.0). ${ }^{19}$ Written informed consent from participating donors and recipients was obtained before collection of questionnaires and whole blood.

\section{RESULTS}

Between May 17 and June 29, 1997, 8984 National Guard members from 10 states (Arkansas, Georgia, lowa, Illinois, Kansas, Missouri, Nebraska, Oklahoma, Tennessee, and Texas) engaged in annual training exercises at the Arkansas military base. Training exercises typically lasted 2 weeks and principally were conducted away, from the barracks, in the field. Threeseparateblood drives wereheld at the military base on May 29-30, June 11-12, and June 25-26, coincident with the final days of each training session. Participants of those blood drives included the visiting National Guard members, as well as a few permanent military and civilian staff members at the military base.

A total of 377 donors were identified who had donated blood at one of the scheduled blood drives at the military base $(n=368)$, or within 4 weeks after having returned home $(n=9)$. Of these donors, 306 (81\%) completed a questionnaire. The median age of donors was 30 years (range, 19-59 years). Seventy-six percent weremale and 1.9 percent were civilian staff at the base. Thirty-seven donors reported fever or rash plus at least one other symptom after donating blood. The convalescent-phase serum samples were collected 2 to 18 weeks (mean, 8 weeks) after the date of blood donation. Twelve of the $37 \mathrm{ill}$ donors also had serologic evidence of recent exposure to either R. rickettsii or $\mathrm{E}$. chaffeensis (Table 2) and were designated as confirmed or probable cases. The average approximate incubation period until the onset of symptoms was 7 days. Five persons sought medical attention (donors 1, 3, 9, 10, and 11 in Table 2) for their illness and one required hospitalization (donor 10) for 2 days. Sixty (16\%) of the 377 donors had evidence of asymptomatic seroconversion: 54 to R. rickettsii and six to E. chaffeensis. Overall, 14.3 percent ( 9 of 63 ) and 40 percent (4 of 10) of the donors with serologic evidence of recent exposureto R. rickettsii and E. chaffeensis, respectively, reported having a clinically compatibleillness. None of the 10 donors tested were positive for antibodies to B. burgdorferi. Polymerase chain reaction testing for pathogen DNA was negative on all blood retention samples from the confirmed and probable cases.

The blood that was collected from the 377 donors was separated into 1020 components, including packed red cells, platelets, and plasma. Of these, 320 units ( 157 packed red cells and 163 platelets) were transfused into 129 recipients in nine states (Alabama, Arkansas, Illinois, lowa, Louisiana, Mississippi, Oklahoma, Texas, and Utah). Physicians of all recipients werecontacted, and none of the 129 recipients had developed symptoms that could beattributableto a tick-borneillness after receiving one of these blood components. Ten recipients received blood from donors who were confirmed or probable cases (Fig. 1). Physicians of these recipients were recontacted and reported that since receiving their transfusions, none of the 10 recipients developed symptoms consistent with a tick-borne illness. Serum samples were forwarded from six recipients; four recipients had either died because of their preexisting medical conditions or were unwilling to participate. Of the six recipients tested, three had positive serologic results with the investigational EIA for IgG to SFG rickettsia. A recipient from Arkansas submitted paired sera that yielded results consistent with past infection with SFG rickettsia, and recipients from Texas and Mississippi had single positive samples, drawn a minimum of 4 weeks after transfusion, that wereconsistent with past infection or asymptomatic seroconversion to SFG rickettsia. Corresponding IgM tests and all IFA results were uniformly negative on these three reci pients.

Tick exposure and awareness were high among the donors-85 percent ( 260 of 306 ) of the questionnaire respondents reported that they had always or sometimes employed at least one tick-bite preventive measure, such as using repellent on their skin or wearing a uniform impregnated with tick repellent. However, 75 percent of the

\begin{tabular}{|c|c|c|}
\hline Status & $\begin{array}{c}\text { Compatible } \\
\text { illness }\end{array}$ & Serology \\
\hline Confirmed case & Yes & $\geq$ Fourfold increase or decrease in paired serum IgG titers by IFA \\
\hline Probable case & Yes & $\begin{array}{l}\geq \text { Fourfold increase or decrease in paired serum IgM titers by IFA or EIA or } \\
\geq \text { Fourfold increase or decrease in paired serum IgG titers by EIA or } \\
\text { Single elevated serum IgG or IgM titer by IFA or EIA }\end{array}$ \\
\hline Asymptomatic seroconversion & No & $\geq$ Fourfold increase or decrease in paired serum IgG or IgM titers by IFA or EIA \\
\hline Past infection & No & $<$ Fourfold increase or decrease in paired serum IgG or IgM titers by IFA or EIA \\
\hline $\begin{array}{l}\text { Either asymptomatic seroconversion } \\
\text { or past infection }\end{array}$ & No & Single elevated serum IgG or IgM titer by IFA or EIA \\
\hline
\end{tabular}




\begin{tabular}{|c|c|c|c|c|c|c|c|c|c|c|c|c|}
\hline \multirow[b]{2}{*}{ Donor } & \multirow[b]{2}{*}{ Antigen } & \multicolumn{2}{|c|}{ Titers } & \multirow[b]{2}{*}{ Fever } & \multirow[b]{2}{*}{ Rash } & \multirow[b]{2}{*}{ Headache } & \multirow[b]{2}{*}{ Myalgia } & \multirow[b]{2}{*}{ Arthralgia } & \multicolumn{2}{|r|}{ Saw } & \multirow{2}{*}{\multicolumn{2}{|c|}{ Hospitalized }} \\
\hline & & 1st samp & le2nd sample & & & & & & Nausea & physician & & \\
\hline 1 & Ec & $<64$ & 1,024 & + & - & + & + & - & + & $\bar{Y}$ & $\mathrm{~N}$ & Confirmed ehrlichiosis \\
\hline 2 & Ec & $<64$ & 2,048 & + & + & + & - & - & - & $\mathrm{N}$ & $\mathrm{N}$ & Confirmed ehrlichiosis \\
\hline 3 & Ec & $<64$ & 512 & + & + & + & + & - & + & $\mathrm{Y}$ & $\mathrm{N}$ & Confirmed ehrlichiosis \\
\hline 4 & $\begin{array}{l}\mathrm{Ec} \\
\mathrm{Br}\end{array}$ & $\begin{array}{r}<64 \\
99\end{array}$ & $\begin{array}{r}64 \\
12801\end{array}$ & - & + & - & + & - & - & $\mathrm{N}$ & $\mathrm{N}$ & $\begin{array}{l}\text { Confirmed ehrlichiosis } \\
\text { and probable RMSF }\end{array}$ \\
\hline 5 & $\mathrm{Rr}$ & 99 & $\begin{array}{r}12,801 \\
6,400\end{array}$ & + & - & + & + & + & + & $\mathrm{N}$ & $\mathrm{N}$ & Probable RMSF \\
\hline 6 & $\mathrm{Rr}$ & 99 & 3,200 & + & - & + & + & + & + & $\mathrm{N}$ & $\mathrm{N}$ & Probable RMSF \\
\hline 7 & $\mathrm{Rr}$ & 99 & 800 & - & + & + & - & + & - & $\mathrm{N}$ & $\mathrm{N}$ & Probable RMSF \\
\hline 8 & $\mathrm{Rr}$ & 99 & 6,400 & - & + & + & + & - & - & $\mathrm{N}$ & $\mathrm{N}$ & Probable RMSF \\
\hline 9 & $\mathrm{Rr}$ & 99 & 1600 & + & + & + & - & - & - & $\mathrm{Y}$ & $\mathrm{N}$ & Probable RMSF \\
\hline 10 & $\mathrm{Rr}$ & 99 & 12,801 & + & + & + & - & - & + & $\mathrm{Y}$ & $\mathrm{Y}$ & Probable RMSF \\
\hline 11 & $\mathrm{Rr}$ & 99 & 1,600 & + & + & + & + & + & - & $\mathrm{Y}$ & $\mathrm{N}$ & Probable RMSF \\
\hline 12 & $\mathrm{Rr}$ & 99 & 12,801 & - & + & + & + & + & + & $\mathrm{N}$ & $\mathrm{N}$ & Probable RMSF \\
\hline
\end{tabular}

Tracking of blood components

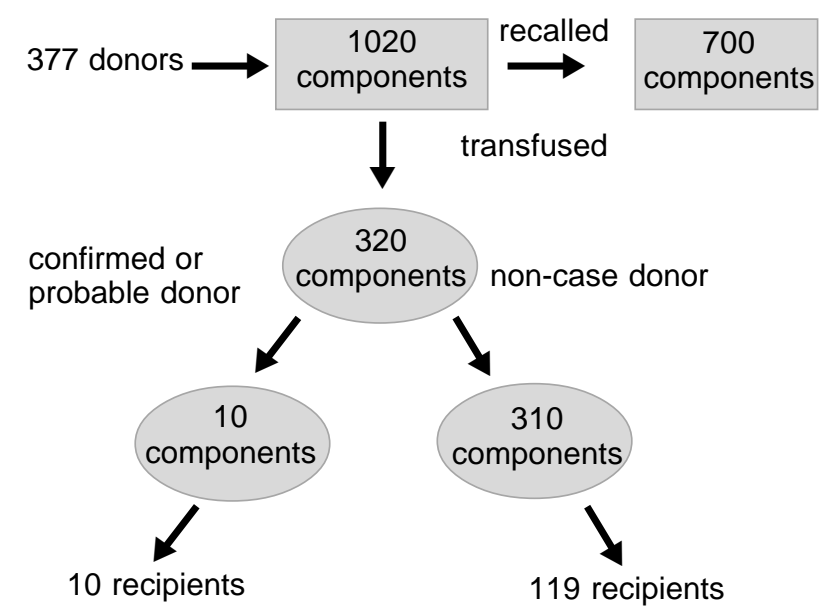

Fig. 1. Tracking of blood components from 377 donors identified as having been in a tick-infested area within the 4 weeks preceding donation.

donors reported finding ticks on their body while at the military base, and 33.5 percent reported morethan 10 ticks on their body during the training period. Only four donors reported prophylactic use of doxycycline.

\section{DISCUSSION}

In the follow-up of the National Guard blood donations, transfusion-associated illness from a tick-borne pathogen was not demonstrated, although transfusion-associated infection could not be ruled out in all cases. One recipient had static IgG titers against SFG rickettsia that were consistent with past infection (Table3). In addition, two recipients submitted single serum samples that tested positive for IgG to SFG rickettsia. From these results, it is impossible to determine if these findings represented past infection, asymptomatic seroconversion, or nonspecific reactivity with theinvestigational EIA. All of thelFA results werenegative, as were IgM assays by EIA. All three individuals were from states where RMSF is endemic, so previous exposure is a possibility. Because no recipient reported the onset of symptoms suggestive of a tick-borne infection after their transfusion, serum samples werenot collected from recipients whose donors were asymptomatic seroconverters or from the seronegative donors who reported being ill with symptoms suggestive of infection.

Passive infection with tick-borne pathogens through blood transfusion has been confirmed for one case of RMSF and multiplecases of babesiosis. ${ }^{2-6}$ In thesecases, therewas a period when the donor was asymptomatic and therefore not deferred from donating blood, yet parasitemia was sufficient to result in transfusion-related disease. Other bacteria, such as B. burgdorferi and Orientia tsutsugamushi, the causative rickettsial agent of scrub typhus, can survive in stored blood products, ${ }^{7-10,20}$ but these pathogens have not been linked to transfusion-related disease. Although the pathogenesis of the human ehrlichiosis is incompletely understood, it is likely that an asymptomatic period occurs in which infected individuals have high enough titers of ehrlichiaecirculating in their blood that it would bepotentially infectious if transfused. Therefore, the potential for transfusion-related disease exists, although themagnitude of the risk is difficult to assess.

There are data to suggest that military training exercises in some locations within the United States placetrainees at exceptionally high risk of exposure to ticks ${ }^{21}$ and tickborne diseases.22,23 In 1989, an outbreak of tick-borne disease coupled with asymptomatic infections occurred among military personnel training at the same base investigated in this report; 38 percent of the training participants were found to have antibodies (singlepositivetiters) against SFG rickettsia ( $n=14$ cases) or ehrlichial antigens ( $n=2$ cases). ${ }^{24}$ As in this study, the majority (67\%) of those persons were asymptomatic or did not havean illness clinically compatible with RMSF or ehrlichiosis. In 1990, a follow up, 


\begin{tabular}{|c|c|c|c|c|}
\hline Donor and status & Recipient & Blood component received & Serology* $^{*}$ & Interpretation \\
\hline 1. Confirmed ehrlichiosis & A & Platelets & $\operatorname{Rr} 1: 800,1: 400$ & Prior RMSF \\
\hline 3. Confirmed ehrlichiosis & $\begin{array}{l}\mathrm{B} \\
\mathrm{C}\end{array}$ & $\begin{array}{l}\text { Platelets } \\
\text { Red cells }\end{array}$ & $\begin{array}{l}\text { Negative } \\
\text { Unable to test }\end{array}$ & \\
\hline 4. Confirmed ehrlichiosis & & & & Prior RMSF or asymptomatic \\
\hline and probable RMSF & $\mathrm{D}$ & Platelets & $\operatorname{Rr} 1: 400$ & Seroconversion \\
\hline 5. Probable RMSF & $\begin{array}{l}\mathrm{E} \\
\mathrm{F}\end{array}$ & $\begin{array}{l}\text { Platelets } \\
\text { Red cells }\end{array}$ & Unable to test & \\
\hline 6. Probable RMSF & G & Platelets & Negative & \\
\hline 9. Probable RMSF & $\mathrm{H}$ & Platelets & Negative & \\
\hline \multirow[t]{2}{*}{ 10. Probable RMSF } & 1 & Platelets & Unable to test & \\
\hline & $\mathrm{J}$ & Red cells & $\operatorname{Rr} 1: 100$ & $\begin{array}{l}\text { Prior RMSF or } \\
\text { asymptomatic seroconversion }\end{array}$ \\
\hline
\end{tabular}

prospective, seroepidemiologic study collecting paired preexposure and postexposure sera from 1194 military trainees was conducted at the sameArkansas base. ${ }^{22}$ Thirty persons (2.5\%) seroconverted to R. rickettssii and 15 (1.3\%) to E. chaffeensis, although once again only about 30 percent of the persons seroconverting reported symptoms indicating a possible tick-borne disease.

The current investigation also identified a number of confirmed or probable cases of RMSF and ehrlichiosis among a larger percentage ( 59 of 71 or $83 \%$ ) of persons with asymptomatic seroconversions or past infections. Between 1981 and 1992, the average annual incidence of reported cases of RMSF was 0.32 case per 100,000 population in the United States and 1.1 cases per 100,000 in Arkansas. ${ }^{12} \mathrm{Al}-$ though not directly comparable, theoccurrenceof probable RMSF among donors who participated in this investigation and who also sought medical attention was 3 of 306, the equivalent of 980 cases per 100,000 population during a 6 week interval. In assessing the magnitude of theoverall situation, one should also consider the potential importance of the large fraction of asymptomatic seroconverting donors. An infection that may be subclinical in a healthy young adult could result in a completely different disease course when transmitted to sick or otherwisecompromised transfusion recipients.

Although serum samples were not obtained from all recipients, no one (including those who received components from asymptomatic seroconverting donors) reported becoming ill with symptoms consistent with a tick-borne disease.

At the time of the investigation and the voluntary recall of the blood components, the CDC and the Food and Drug Administration (FDA) advised all individuals who participated in training exercises at the military base during April through June not to donate blood within 4 weeks of their departure. In addition, blood drives there weresuspended until September, when the tick season usually is over. On the basis of discussions among representatives from the CDC, FDA, and the Department of Defense (DOD), the FDA has concluded that blood or plasma collection at this military base during the tick season is safe, provided that no unit is collected more than 48 hours after the potential donor arrives at the base. In addition, the FDA has determined that these trainees will again be advised not to donate blood or plasma for at least 4 weeks after leaving the base. ${ }^{25}$ DOD, however, decided not to allow blood collections at this military base in 1998 and 1999.

The potential for transfusion of tick-borne pathogens remains a concern, both within the military and among civilian blood collection agencies. A workshop to review the epidemiology and biology of tick-borne agents with the potential to betransmitted by transfusion washeld in Georgia, January 1999, to help agencies responsible for the safety of blood components obtain the background information on these subjects so that appropriate steps can be taken to reduce the risk of transfusion-related infection without mandating unrealistic screening procedures at collection centers.

\section{ACKNOWLEDGMENTS}

The authors acknowledge the contributions of several people to this investigation: Carolyn Bridges and Rima Khabbaz (DVRD, NCID, CDC); Karen Buechler, Russell Currier, and Judy Goddard (lowa Department of Public Health); Paul Jenner and Hany Kamel (Blood Systems, Inc.); Michele Cote, Kristin Moody, and Laura Smithee (Oklahoma State Health Department); James Foote (Arkansas National Guard); Byron Francis and Carl Langkop (Illinois Health Department); Ned Hayes (Division of Vector-Borne Infectious Diseases, NCID, CDC); Cathy Lasiter and William Moore (Tennessee Health Department); Louise McFarland (Louisiana Department of Health and Hospitals); Gianfranco Pezzino (Kansas Department of Health and Environment); Julie Rawlings and J eff Taylor (Texas Health Department); Sharon Thompson (Alabama Department of Public Health); and Jay Epstein (Office of Blood Research and Review, FDA).

The Transfusion-Associated Tick-Borne Illness Task Force included: L. Beati, D. Berry, B. Bracken, J.A. Comer, J.M. 
Crutcher, K. Dubois, B. Ellis, S. Hand, D. Jones, D. Leshinsky, E. Mandel, R. Massung, T. McChesney, D.B. McKechnie, W.L. Nicholson, C.D. Paddock, G.J. Pelligrini, P. Quinlisk, R. Regnery, J. Rhiner, J. Rooney, T. Safranek, and M.E. Schreifer.

\section{REFERENCES}

1. Chamberland M, Khabbaz RF. Emerging issues in blood safety. Infect Dis Clin North Am 1998;12:217-29.

2. Gerber MA, Shapiro ED, Krause PJ, et al. The risk of acquiring Lyme disease or babesiosis from a blood transfusion. J Infect Dis 1994;170:231-4.

3. Mintz ED, Anderson JF, Cable RG, Hadler JL. Transfusiontransmitted babesiosis: a case report from a new endemic area. Transfusion 1991;31:365-8.

4. Herwaldt BL, Kjemtrup AM, Conrad PA, et al. Transfusiontransmitted babesiosis in Washington State: first reported case caused by a WA1-type parasite. J Infect Dis 1997;175:1259-62.

5. Marcus LC, Valigorsky JM, Fanning WL, et al. A case report of transfusion-induced babesiosis. JAMA 1982;248:465-7.

6. Wells GM, Woodward TE, Fiset P, Hornick RB. Rocky Mountain spotted fever caused by blood transfusion. JAMA 1978;239:2763-5.

7. Baranton $G$, Saint-Girons I. Borrelia burgdorferi survival in human blood samples. Ann N Y Acad Sci 1988;539:444-5.

8. Johnson SE, Swaminathan B, Moore P, et al. Borrelia burgdorferi: survival in experimentally infected human blood processed for transfusion. J Infect Dis 1990;162:5579.

9. Nadelman RB, Sherer C, Mack L, et al. Survival of Borrelia burgdorferi on human blood stored under blood banking conditions. Transfusion 1990;30:298-301.

10. Badon SJ, Fister RD, Cable RG. Survival of Borrelia burgdorferi in blood products. Transfusion 1989;29:581-3.

11. Yamashita CA, Mielle A, Renko NS, et al. Parinaud syndrome caused by Bartonella henselae: case report. Rev Inst Med Trop Sao Paulo 1996;38:437-40.

12. Dalton MJ, Clarke MJ, Holman RC, et al. National surveillance for Rocky Mountain spotted fever, 1981-1992: epidemiologic summary and evaluation of risk factors for fatal outcome. Am J Trop Med Hyg 1995;52:405-13.

13. Oaks SC Jr, Ng FK, Elwell MR, et al. Pathology of toxic death in mice following intravenous injection of Rickettsia tsu- tsugamushi strain gilliam: examination by light and scanning electron microscopy. Jpn J Med Sci Biol 1985;38:67-72.

14. Nicholson WL, Comer JA, Sumner JW, et al. An indirect immunofluorescence assay using a cell culture-derived antigen for detection of antibodies to the agent of human granulocytic ehrlichiosis. J Clin Microbiol 1997;35:1510-6.

15. Dawson JE, Rikihisa Y, Ewing SA, Fishbein DB. Serologic diagnosis of human ehrlichiosis using two Ehrlichia canis isolates. J Infect Dis 1991;163:564-7.

16. Recommendations for test performance and interpretation from the second national conference on serologic diagnosis of Lyme disease. MMWR Morb Mortal Wkly Rep 1995;44:590-1.

17. Regnery RL, Spruill CL, Plikaytis BD. Genotypic identification of rickettsiae and estimation of intraspecies sequence divergence for portions of two rickettsial genes. J Bacteriol 1991;173:1576-89.

18. Anderson BE, Sumner JW, Dawson JE, et al. Detection of the etiologic agent of human ehrlichiosis by polymerase chain reaction. J Clin Microbiol 1992;30:775-80.

19. SPSS for Windows. Version 7.0. Chicago: SPSS, 1996.

20. Casleton BG, Salata K, Dasch GA, et al. Recovery and viability of Orientia tsutsugamushi from packed red blood cells and the danger of scrub typhus from blood transfusion. Transfusion 1998;38:680-9.

21. Goddard J, McHugh CP. Impact of a severe tick infestation at Little Rock AFB, Arkansas on volant scorpion military training. Mil Med 1990;155:277-80.

22. Yevich SJ, Sanchez JL, DeFraites RF, et al. Seroepidemiology of infections due to spotted fever group rickettsiae and Ehrlichia species in military personnel exposed in areas of the United States where such infections are endemic. J Infect Dis 1995;171:1266-73.

23. Petersen LR, Sawyer LA, Fishbein DB, et al. An outbreak of ehrlichiosis in members of an Army Reserve unit exposed to ticks. J Infect Dis 1989;159:562-8.

24. Sanchez JL, Candler WH, Fishbein DB, et al. A cluster of tick-borne infections: association with military training and asymptomatic infections due to Rickettsia rickettsii. Trans $\mathrm{R}$ Soc Trop Med Hyg 1992;86:321-5.

25. Recommendations for testing blood specimens collected from Ft. Chaffee (Arkansas) National Guard personnel (letter to US blood banks. Washington: US Department of Health and Human Services, June 23, 1998. [ 